\title{
Hydroxylation of polypropylene using the monooxygenase mutant 139-3 from Bacillus megaterium BM3
}

\author{
ANDREA HASMANN ${ }^{2}$, ANITA EBERL ${ }^{2}$, KONSTANTIN SCHNEIDER $^{2}$, \\ KAI-UWE SCHOENING ${ }^{3}$, FRANZ KAUFMANN ${ }^{3}$, ANTON GLIEDER ${ }^{2}$, JANEZ KOVAČ ${ }^{4}$, \\ ARTUR CAVACO-PAULO ${ }^{5}$, EVA WEHRSCHUETZ-SIGL ${ }^{2}$ \\ \& GEORG MAXIMILLIAN GUEBITZ ${ }^{1,2}$ \\ ${ }^{1}$ Department of Environmental Biotechnology, Graz University of Technology, Petersgasse 12, Graz, Austria, \\ ${ }^{2}$ ACIB GmbH, Petersgasse 14, Graz, Austria, ${ }^{3}$ BASF Schweiz AG, Klybeckstrasse, Basel, Switzerland, \\ ${ }^{4}$ FoséfŠtefan Institute, Famova 39, Ljubljana, and ${ }^{5}$ Department of Textile Engineering, \\ University of Minho, Guimaraes, Portugal
}

\begin{abstract}
Enzymatic hydroxylation of polypropylene (PP) was investigated in order to increase hydrophilicity, A mutant (139-3) of the P450monooxygenase from Bacillus megaterium expressed in E. coli $\mathrm{DH} 5 \alpha$ was purified using anion exchange chromatography. Hydroxylation of PP fabrics led to a dramatic increase of hydrophilicity as indicated by a water drop dissipation time of below $1 \mathrm{~s}$ compared to the hydrophobic reference material. Likewise, a $4.9 \mathrm{~cm}$ increase of rising height was measured which remained consistent after $144 \mathrm{~h}$ of storage. Similarly, enzymatic hydroxylation of PP films lead to a decrease of the WCA from $104.6^{\circ}$ to $77.3^{\circ}$ with no major change after exposure to air for 6 days. Using X-ray photoelectron spectroscopy, an increase in normalized atomic concentrations of oxygen from 1.40 to $4.98 \%$ for the CO-inhibited and enzyme treated sample, respectively, was measured confirming enzymatic hydroxylation.
\end{abstract}

Keywords: oxidoreductase, polypropylene, polymer, surface modification

\section{Introduction}

The properties of polyolefins regarding further functionalization can be considerably improved by the introduction of polar groups onto the surface (Naga et al. 2006). A number of chemical and plasma based methods have been developed for this purpose (Cui et al. 2002; Favaro et al. 2007). While with chemical methods such as the incorporation of hydroxylated cyclic molecules the polymer bulk properties can be tuned (e.g. glass transition temperature, $T_{\mathrm{g}}$ ), plasma based processes target mainly surface properties such as wettability and adhesion (Cui et al. 2002; Favaro et al. 2007). Argon plasmas lead to bond scission creating active sites on the surface while oxygen plasmas additionally lead to surface oxidation (Beake et al. 1998; Han et al. 1999). Among plasma treatment techniques, air discharges are widely used. They are inexpensive since there is no need for a vacuum and, thus, also suitable for continuous processes treating large areas. In contrast, complex three dimensional devices are more difficult to functionalize with such techniques. Enzymatic surface modification in aqueous solution could offer an environmentally friendly alternative working under mild conditions and without high energy consumption.

There are several successful reported examples of surface modification of synthetic polymers including polyalkyleneterephthalates, polyamides and polyacrylonitriles using mainly hydrolases (Guebitz \& Cavaco-Paulo 2008). Polyetheleneterephthalate was hydrolyzed by enzymes, and half a dozen enzymes hydrolyzing PAT films, fibres and nano-particles were identified (Brueckner et al. 2008; Donelli et al. 2009, 2010; Eberl et al. 2008, 2009; Herrero-Acero et al. 2011; Ribitsch et al. 2011; Vertommen et al. 2005). Similarly, enzymatic hydrolysis of polyacrylonitrile either down to the corresponding acid or to the amide has been described (Fischer-Colbrie et al. 2006, 2007). Recently, a new enzyme hydrolyzing polyamide oligomers was crystallized (Negoro et al.

Correspondence: G. M. Guebitz, Department of Environmental Biotechnology, Graz University of Technology, Petersgasse 12, 8010 Graz, Austria. Tel: +433168738312.Fax:+433168738815. E-mail: guebitz@tugraz.at 
2005) while cutinases and amidases have been described to hydrolyze various polyamides (Heumann et al. 2009). However, despite the potential for mild and specific enzymatic surface modification, enzymatic functionalization of polypropylene (PP) has not been exploited yet. Here, the potential of P450 monooxygenases from Bacillus megaterium BM3 for hydroxylation of PP was assessed.

\section{Material and methods}

Cultivation of recombinant E. coli DH5 $\alpha$ and expression of P450 BM-3 monooxygenases

Two recombinant $(0821 \mathrm{~B} ; 139-3)$ and the wild-type P450 monooxygenase from Bacillus megaterium (BM-3) were expressed in E. coli DH5 $\alpha$. The mutant monooxygenases were developed using a combination of directed evolution and site-directed mutagenesis in order to improve their ability to hydroxylate linear alkanes (Glieder et al. 2002). Recombinant $E$. coli $\mathrm{DH} 5 \alpha$ containing genes encoding different $P 450$ $B M-3$ mutants were plated on LB agar plates containing $100 \mathrm{mg} / \mathrm{L}$ ampicillin, and were grown for 12 $\mathrm{h}$ at $37^{\circ} \mathrm{C}$. Single colonies were picked for the inoculation of $5 \mathrm{~mL}$ TB-amp-medium. These precultures were cultivated at $30^{\circ} \mathrm{C}$ and $130 \mathrm{rpm}$ for $12 \mathrm{~h}$, to reach a uniform cell density at the beginning of their stationary growth phase. Thereafter, $1000 \mathrm{~mL}$ Erlenmeyer flasks containing $250 \mathrm{~mL}$ TB-ampmedium (supplemented with $100 \mu \mathrm{g}$ ampicillin $/ \mathrm{mL}$ and $1.5 \mu \mathrm{L}$ trace elements is oc) were inoculated with 1 $\mathrm{mL}$ of the overnight cultures of recombinant E. coli $\mathrm{DH} 5 \tilde{\alpha}$. After $24 \mathrm{~h}$ of incubation, $125 \mu \mathrm{L}$ 5-aminolevulinic acid hydrochloride (1 M stocksolution) which acts as a heme precursor was added per $250 \mathrm{~mL}$ media. After $2 \mathrm{~h}$, the expression was induced by adding $250 \mu \mathrm{L}$ IPTG $(0.5 \mathrm{M}$ stocksolution) and $125 \mu \mathrm{L}$ ampicillin. After $7 \mathrm{~h}$, the medium was supplemented with $125 \mu \mathrm{L} 5$-aminolevulinic acid hydrochloride, $250 \mu \mathrm{L}$ IPTG and $125 \mu \mathrm{L}$ ampicillin per $250 \mathrm{~mL}$ culture. After $15 \mathrm{~h}$, cells were harvested by centrifugation at $4500 \mathrm{~g}$ for $20 \mathrm{~min}$ and washed with Tris/ $\mathrm{HCl}$ buffer ( $30 \mathrm{mM}, \mathrm{pH} 7.5)$. Cells were stored until further use at $-20^{\circ} \mathrm{C}$ in this buffer. All chemicals were purchased from Sigma.

\section{Enzyme purification}

Cells were suspended in $5 \mathrm{~mL}$ Tris/ $\mathrm{HCl}$ buffer ( $30 \mathrm{mM}, \mathrm{pH} 7.5$ ) and then sonicated for $3 \mathrm{~min}$. The crude suspension was centrifuged for $60 \mathrm{~min}$ at 18000 g. The resulting supernatant was diluted with buffer to a final volume of $25 \mathrm{~mL}$ and was then filtered through a sterile filter $(0.5 \mu \mathrm{m})$. Proteins (sample volume of $10 \mathrm{~mL}$ ) were separated using an anionexchange column (HiPrep 16/10 QFF, $17 \mathrm{~mL}$, from Pharmacia) with $30 \mathrm{mM}$ Tris/HCl buffer $(\mathrm{pH} 7.5)$ as eluent at a flow rate of $5 \mathrm{~mL} / \mathrm{min}$. Proteins were eluted with increasing salt-concentration $(1 \mathrm{M} \mathrm{NaCl})$ simultaneously monitoring absorbance at $280 \mathrm{~nm}$ (protein) and $417 \mathrm{~nm}$ (heme). The most active fractions (brown coloured) were pooled together and frozen at $-20^{\circ} \mathrm{C}$.

\section{Enzyme assays}

The CO-binding-assay was used for quantification of functional P450-enzyme based on complex formation of reduced cytochrome $\mathrm{P} 450$ ( $\mathrm{Fe}^{\mathrm{II}}$ ) with carbon-monoxide (CO) absorbing at $450 \mathrm{~nm}$. For the measurement, $3 \mathrm{~mL}$ purified protein-solution (in Tris/ $\mathrm{HCl}$ buffer, $30 \mathrm{mM}, 1 \mathrm{M} \mathrm{NaCl}$ ) were pipetted into a plastic tube and $10 \mu \mathrm{L}$ of methyl viologen dichloride hydrate $(1 \%(\mathrm{w} / \mathrm{v})$ in distilled water) were added as a redox indicator. Samples were reduced using sodium hydrosulfite with a final concentration of $20 \mathrm{mM}$. After mixing, the sample was separated into two portions. $\mathrm{CO}$ was bubbled through one of the samples for $1 \mathrm{~min}$ (approximately 1 bubble per second) while the second sample was used as a reference. A spectrum was run from $390 \mathrm{~nm}$ to $500 \mathrm{~nm}$ under aerobic conditions and the concentration of monooxygenases was calculated based on an extinction coefficient of $91\left[\mathrm{mM}^{-1} \mathrm{~cm}^{-1}\right]$.

Monooxygenase activity was quantified based on the conversion of $p$-nitrophenoxyoctane (8-pNA) to $\widetilde{\omega}$-oxyoctane and the chromophore $p$-nitrophenolate (Schwaneberg et al. 1999a); $50 \mu \mathrm{L}$ enzyme solution and $3 \mu \mathrm{L}$ of a $50 \mathrm{mM}$ solution of 8-pNA in Dimethyl sulfoxide (DMSO) were added to $910 \mu \mathrm{L} \mathrm{KPi} \mathrm{buffer}$ (50 $\mathrm{mM}, \mathrm{pH} 8.0$ ). The reaction was started by the addition of $30 \mu \mathrm{L}$ of an aqueous solution of $6 \mathrm{mM}$ Nicotinamide adenine dinucleotide phosphate $(\mathrm{NADPH})$ and run for $100 \mathrm{~s}$ at $30^{\circ} \mathrm{C}$. As a reference, $940 \mu \mathrm{L}$ buffer were used. Formation of $p$-nitrophenolate was monitored at $410 \mathrm{~nm}$ and enzyme activity was given in nkat representing the conversion of 1 nmol 8-pNA per second. For the synthesis of 8-pNA, 1-bromoooctane (17 mmol, $2.96 \mathrm{~mL}$ ), p-nitrophenolate $(18.5 \mathrm{mmol}, 2.98 \mathrm{~g})$ and ethanol absolute $(50 \mathrm{~mL})$ were combined in a $100 \mathrm{~mL}$ round bottom flask fitted with a water-cooled reflux condenser. KI was added to act as catalyst and the reaction solution refluxed at $80^{\circ} \mathrm{C}$ for $16 \mathrm{~h}$. The alcohol was removed with a vigreux-colonne. To the resulting residue, $15 \mathrm{~mL}$ of a $5 \%(\mathrm{w} / \mathrm{v})-\mathrm{NaOH}$ solution was added and the organic phase was re-dissolved in diethylether, washed with water and dried over sodium sulphate. Afterwards, the solvent was removed by heating and the product recrystallized twice. The 
structure was confirmed by Nuclear magnetic resonance spectroscopy, NMR (Varian Unity Inova 500 instrument).

\section{Enzyme treatment of polypropylene materials}

For a pre-screening, NADPH depletion as a measure of substrate hydroxylation was measured based on fluorescent emission at $445 \mathrm{~nm}$ when excited at 340 $\mathrm{nm}$. Fabric samples of $2 \times 2 \mathrm{~mm}$ were incubated in microtiter plates containing 1 nkat $\mathrm{mL}^{-1}$ of monooxygenase and $0.5 \mathrm{mM}$ NADPH in $300 \mu \mathrm{L}$ of $100 \mathrm{mM}$ phosphate buffer at $30^{\circ} \mathrm{C}$.

For detailed analysis, PP fabrics and films (Ciba Inc.) were cut into pieces of $4 \times 6 \mathrm{~cm}$, and incubated in $100 \mathrm{~mL}$ Erlenmeyer flasks in $4.5 \mathrm{~mL}$ of $30 \mathrm{mM}$ Tris/ $\mathrm{HCl}$ buffer with different monooxygenase activities, incubation times and temperatures as indicated below. Erlenmeyer flasks were shaken at $250 \mathrm{rpm}$ on an orbital shaker. To remove adsorbed enzymes or media impurities, the fabrics were washed with $\mathrm{Na}_{2} \mathrm{CO}_{3}(1 \mathrm{~g} / \mathrm{L}, \mathrm{pH}$ 9.5) for $2 \mathrm{~h}$ and with distilled water for $1 \mathrm{~h}$. Afterwards, the samples were dried at $100^{\circ} \mathrm{C}$ overnight.

\section{Inhibition of monooxygenase activity}

For inhibition of monooxygenase activity, oxygen was removed from the above incubation mixture by flushing with nitrogen for $10 \mathrm{~min}$. Subsequently, the mixture was flushed with $\mathrm{CO}$ for half an hour, and the PP sample was added and the vessel closed for incubation as described above.

\section{Quantification of hydrophilicity increase}

Hydrophilicity was quantified based on the rising height of water on fabric samples due to capillary forces (DIN 53924). Fabrics were fixed on a rod above a water bath immersed in the water for $1 \mathrm{~cm}$, and after $10 \mathrm{~min}$, the water level on the fabrics was measured in centimetres. Alternatively, the water drop dissipation test was used. A drop $(20 \mu \mathrm{L}$ distilled water) was placed on the surface of the fabric, and the time until dissipation was measured in seconds. For PP-films the contact angle, $\varphi$, between a water drop and the film surface was measured with the Drop Shape Analysis System DSA 100 (Krüss $\mathrm{GmbH}$, Hamburg, Germany). Deionized water was used as test liquid with a drop size of $3 \mu \mathrm{L}$. The contact angle was measured after $3 \mathrm{~s}$, and the data were obtained from the averages of the measurements taken from 10 different points of the sample surface. To estimate protein adsorption on samples, a $1 \%(\mathrm{w} / \mathrm{v})$-solution of ninhydrin in ethanol was prepared. PP pieces were sprayed with this solution and then dried in a heating chamber at $100^{\circ} \mathrm{C}$ for half an hour.

\section{XPS analysis}

XPS analysis was carried out on a PHI-TFA spectrometer (Physical Electronic Inc.). PP samples were fixed in position and three different sample locations analyzed from two experimental series. The analyzed area was $0.4 \mathrm{~mm}$ in diameter, and the analyzed depth was about 3-5 nm. X-ray excitation was achieved with a monochromatic Al source at photon energy of $1486.6 \mathrm{eV}$. Wide-scan spectra were acquired at pass energy of $187 \mathrm{eV}$ for identification and quantification of elements on the surfaces of the fabrics. The atomic concentrations of surface regions were calculated using relative sensitivity factors provided by the manufacturer. Highenergy resolution spectra of $\mathrm{C} 1 \mathrm{~s}, \mathrm{O} 1 \mathrm{~s}$ and $\mathrm{S} 2 \mathrm{p}$ were acquired with an energy resolution of about $0.6 \mathrm{eV}$ with analyzer pass energy of $29 \mathrm{eV}$, to reveal binding energies of XPS peaks associated with different chemical states of elements.

\section{Results and discussion}

In recent years, the potential of hydrolases for surface modification of synthetic polymers including polyethylene terephthalate, polyamide and polyacrylonitriles has been demonstrated (Brueckner et al. 2008; Eberl et al. 2008, 2009; Fischer-Colbrie et al. 2006; Heumann et al. 2009).

For PP, which is not a substrate for hydrolases, oxidoreductases have been investigated for indirect enzymatic coating with phenolic molecules (Schroeder et al. 2008). In this study, direct enzymatic hydroxylation of PP was investigated.

For this purpose, monooxygenases from Bacillus megaterium $\mathrm{BM} 3$ were used which were previously designed by a combination of directed evolution and site-directed mutagenesis to hydroxylate linear alkanes (Glieder et al. 2002). The wild type enzyme and two mutants $139-3$ and $B$ were successfully expressed in E. coli $\mathrm{DH} 5 \alpha$ and monooxygenases purified from the cell lysates using anion exchange chromatography. In an initial screening with these enzymes increased depletion of the cofactor NADPH was seen in the presence of PP when compared to enzyme and PP controls. The most pronounced increases were seen for the mutant 139-3 (data not shown). These results can only be regarded as qualitative estimation since oxidation of NADPH can become uncoupled from substrate oxidation (Peters et al. 2003). However, 
these findings were still encouraging for a detailed investigation of PP hydroxylation with $\mathrm{P} 450$ BM3_139-3.

P450_BM3_139-3 was obtained in a one-step purification procedure using anion-exchange chromatography as previously described (Schwaneberg et al. $1999 \mathrm{a}, \mathrm{b}$ ) simultaneously monitoring protein and $\mathrm{p} 450$ concentration at 280 and $417 \mathrm{~nm}$. The enzyme preparation had a p450 content of 16.3 $\mu \mathrm{Mol}$. A rate of $68.9 \mathrm{nkat} \mathrm{ml}^{-1}$ was measured at the temperature optimum, $44^{\circ} \mathrm{C}$ when using 8 -pNA as substrate with 54.0 and $37.8 \mathrm{nkat} \mathrm{ml}^{-1}$ at 37 and $30^{\circ}$. However, at the optimum temperature, the enzyme showed a half-life time of only $210 \mathrm{~min}$, while no significant activity loss was seen at $30^{\circ} \mathrm{C}$ after $12 \mathrm{~h}$ of incubation. Consequently, PP hydroxylation was carried out at $30^{\circ} \mathrm{C}$.

P450_BM3_139-3 treatment of PP fabrics lead to a dramatic increase in hydrophilicity. No water drop dissipation was seen at all with the very hydrophobic reference material while the dissipation time decreased to 4, 2 and below $1 \mathrm{~s}$ after incubation with 2 nkat $\mathrm{mL}^{-1}$ of P450_BM3_139-3 for 2, 5 and $10 \mathrm{~h}$, respectively. These results were confirmed using the rising height method (Table I).

The hydrophilicity increase measured after P450_BM3_139-3 treatment was clearly primarily due to enzymatic hydroxylation, rather than due to protein adsorption, since carbon monoxide inhibited enzyme did not cause a very significant effect. Similarly, incubation of PP with heat inactivated enzyme preparations as well as with BSA (identical protein concentration) did not give any hydrophilicity increase over an incubation period of $24 \mathrm{~h}$ (data not shown). The hydrophilicity increase, depended on enzyme activity dosed, was quite permanent during exposure to air for $144 \mathrm{~h}$, after an initial decrease of hydrophilicity between $24 \mathrm{~h}$ and $48 \mathrm{~h}$ exposure. A small decrease of hydrophilicity upon prolonged exposure to air has also been seen

Table I. Hydrophilicity of PP-fabrics (Rising height [cm]) incubated for $5 \mathrm{~h}$ with Bacillus megaterium BM3 (mutant 139-3) P450 monooxygenase and measured after different storage times.

\begin{tabular}{lcccc}
\hline & \multicolumn{4}{c}{ Storage time $[\mathrm{h}]$} \\
\cline { 2 - 5 } & $24 \mathrm{CO}^{\mathrm{a}}$ & 24 & 48 & 144 \\
\cline { 2 - 5 } Enzyme treatment $[\mathrm{h}]$ & \multicolumn{2}{l}{ Rising height $[\mathrm{cm}]$} \\
\hline 10 & 0.6 & 4.9 & 4.6 & 4.6 \\
5 & 0.2 & 3.6 & 3.2 & 3.2 \\
2 & 0.0 & 2.3 & 2.0 & 1.9 \\
1 & 0.0 & 1.1 & 0.5 & 0.4 \\
\hline
\end{tabular}

${ }^{\mathrm{a} C O}$-inhibited enzyme.
Table II. XPS analysis of PP films treated with Bacillus megaterium BM3 (mutant 139-3) P450 monooxygenase.

\begin{tabular}{lccc}
\hline Sample & $\begin{array}{c}\text { C } 1 \mathrm{~s} \\
\text { aliphatic }\end{array}$ & $\begin{array}{c}\mathrm{C} 1 \mathrm{~s} \\
\mathrm{CO} / \mathrm{CN}\end{array}$ & $\begin{array}{c}\mathrm{C} 1 \mathrm{~s} \\
\mathrm{COO} / \mathrm{CON}\end{array}$ \\
\hline & $285 \mathrm{eV}$ & $286.6 \mathrm{eV}$ & $288.4 \mathrm{eV}$ \\
Control & 96.2 & 3.4 & 0.4 \\
Enzyme & 74.0 & 18.6 & 7.3 \\
Enzyme $+\mathrm{CO}^{\mathrm{a}}$ & 86.5 & 9.9 & 3.6 \\
\hline
\end{tabular}

${ }^{\mathrm{a} C O}$-inhibited enzyme.

for PP treated with dielectric barrier discharge plasma (Cui et al. 2002).

In addition to PP-fabrics, PP-films were treated with P450_BM3_139-3. In contrast to PP-fabrics, determination of hydrophilicity increases via changes in the contact angle to water was possible. Compared to a reference $\left(104.6^{\circ}\right)$, the contact angle decreased to $77.3^{\circ}$ after $5 \mathrm{~h}$ incubation with $2 \mathrm{nkat} \mathrm{ml}^{-1}$ P450_BM3_139-3. After 6 days of exposure to air this value only changed to $75.7^{\circ}$. Relaxation and reorientation of polar groups during exposure to air has been previously described as responsible for partial recovery (around $5^{\circ}$ after $143 \mathrm{~h}$ ) of the contact angle of dielectric barrier discharge plasma treated PP-films (Cui et al. 2002). Using this method, the contact angle of PP-films could be reduced to about $30^{\circ}$ compared to $27^{\circ}$ using the enzyme approach in this study.

$\mathrm{X}$-ray photoelectron spectroscopy was used to quantify the chemical changes on the polymer surface. Upon treatment with P450_BM3_139-3 normalized atomic concentrations of oxygen increased to 1.40 and $4.98 \%$ for the CO-inhibited and enzyme treated sample, respectively, when corrected for the amount of oxygen resulting from silicon oxide present as filler.

According to the $\mathrm{C} 1 \mathrm{~s}$ detail in the spectra for the three samples, clear differences were observed between enzyme treated samples and controls. The control sample contains mainly aliphatic hydrocarbon with a binding energy of $285 \mathrm{eV}$ as expected for PP. After enzyme treatment, two more species appeared. Their higher binding energies are typical of binding states with higher oxidation, indeed the signal at around $286.6 \mathrm{eV}$ can be assigned to species like $-\mathrm{CH}_{2}-\mathrm{O}(\mathrm{C}-\mathrm{O})$ or $-\mathrm{CH}_{2}-\mathrm{N}(\mathrm{C}-\mathrm{N})$ and the signal at $288.4 \mathrm{eV}$ to carbon from carboxylic acids, esters or amides $(\mathrm{COO} / \mathrm{CON})$ (Table II).

The increase of $-\mathrm{CH}_{2}-\mathrm{O}$ species can be attributed to hydroxylation of PP by P450_BM3_139-3. However, the signal at $288.4 \mathrm{eV}$ corresponding to carbon from carboxylic acids, esters or amides probably results from enzyme (= protein) adsorbed to PP. This is also evident from a nitrogen content of $5.4 \%$ indicating some irreversible enzyme adsorption. 


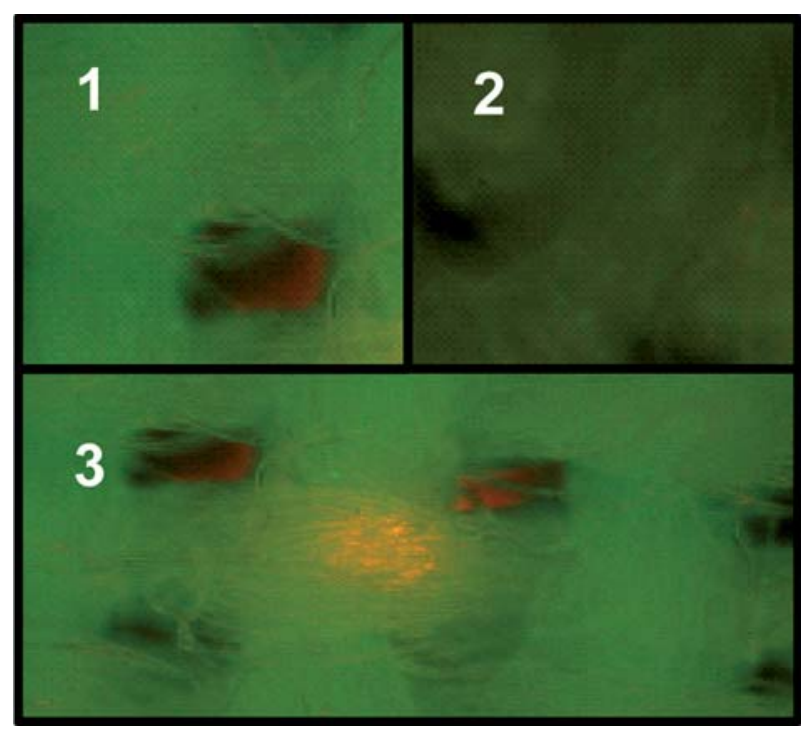

Figure 1. PP-fabrics incubated with FITC labelled BSA in the presence $(1,3)$ and absence (2) of Bacillus megaterium BM3 (mutant 139-3) P450 monooxygenase.

However, as noted there was neither an increase in wettability (see above) nor an increase in the nitrogen content when thermally inactivated P450_ BM3_139-3 was incubated with PP. Thus, it seems that partial hydroxylation with concomitant hydrophilization promotes enzyme/protein adsorption. To confirm this effect, in addition to P450 BM3_139-3, fluorescently (FITC) labelled BSA was added to the incubation mixture. Interestingly enough, only in the presence of P450_BM3_139-3, FITC labelled BSA strongly adsorbed to the surface of PP and could not be removed with various washing procedures (Figure 1).

Irreversible adsorption of enzyme during treatment of synthetic materials has previously been reported for polyethyleneterephtalate. Using XPS analysis, an increase in the nitrogen content of up to $7.2 \%$ due to adsorption of lipase to PET was measured (Vertommen et al. 2005). Using angle resolved XPS, a protein layer thickness of $1.6-2.6 \mathrm{~nm}$ and 2.5-2.8 $\mathrm{nm}$ for cutinase and lipase, respectively, was measured. As in this study, washing even using ultrasound or organic solvents did not significantly decrease enzyme adsorption. In another study focusing on PET, it was demonstrated that severe washing procedures can remove adsorbed enzymes from PET (Brueckner et al. 2008), which, however, did not work for PP in this study.

\section{Conclusions}

Enzymatic hydroxylation of PP was demonstrated to dramatically enhance hydrophilicity. Introduction of oxygen was confirmed by XPS, however, concomitant strong enzyme adsorption was observed. Future studies should focus on the effect of surface active molecules to decrease enzyme adsorption during hydroxylation. In addition, a wider range of hydroxylation enzymes should be investigated, for example, enzymes such as peroxygenases which do not depend on expensive co-factors.

Declaration of interests: This study was performed within Austrian Centre of Industrial Biotechnology ACIB, the MacroFun project and COST Action 868. This work has been supported by the Federal Ministry of Economy, Family and Youth (BMWFJ), the Federal Ministry of Traffic, Innovation and Technology (bmvit), the Styrian Business Promotion Agency SFG, the Standortagentur Tirol and ZIT - Technology Agency of the City of Vienna through the COMET-Funding Program managed by the Austrian Research Promotion Agency FFG.

The authors report no conflicts of interest. The authors alone are responsible for the content and writing of the paper.

\section{References}

Beake BD, Ling JSG, Leggett GJ. 1998. Correlation of friction, adhesion, wettability and surface chemistry after argon plasma treatment of poly(ethylene terephthalate). J Mater Chem 8:2845-2854.

Brueckner T, Eberl A, Heumann S, Rabe M, Guebitz GM. 2008. Enzymatic and chemical hydrolysis of poly(ethylene terephthalate) fabrics. J Polymer Sci Polymer Chem 46:6435-6443.

Cui NY, Brown NMD. 2002. Modification of the surface properties of a polypropylene (PP) film using an air dielectric barrier discharge plasma. Appl Surf Sci 189:31-38.

Donelli I, Taddei P, Smet PF, Poelman D, Nierstrasz VA, Freddi G. 2009. Enzymatic surface modification and functionalization of PET: a water contact angle, FTIR, and fluorescence spectroscopy study. Biotechnol Bioeng 103:845-56.

Donelli I, Freddi G, Nierstrasz VA, Taddei P. 2010. Surface structure and properties of poly-(ethylene terephthalate) hydrolyzed by alkali and cutinase. Polymer Degrad Stabil 95: 1542-1550.

Eberl A, Heumann S, Kotek R, Kaufmann F, Mitsche S, CavacoPaulo A, Guebitz GM. 2008. Enzymatic hydrolysis of PTT polymers and oligomers. J Biotechnol 135:45-51.

Eberl A, Heumann S, Brueckner T, Araujo R, Cavaco-Paulo A, Kaufmann F, Kroutil W, Guebitz GM. 2009. Enzymatic surface hydrolysis of poly(ethylene terephthalate) and bis (benzoyloxyethyl) terephthalate by lipase and cutinase in the presence of surface active molecules. J Biotechnol 143: 207-212.

Favaro SL, Rubira AF, Muniz EC, Radovanovic E. 2007. Surface modification of HDPE, PP, and PET films with $\mathrm{KMnO} 4 / \mathrm{HCl}$ solutions. Polymer Degrad Stabil 92:1219-1226.

Fischer-Colbrie G, Herrmann M, Heumann S, Puolakka A, Wirth A, Cavaco-Paulo A, Guebitz G. 2006. Surface modification of 
polyacrylonitrile with nitrile hydratase and amidase from Agrobacterium tumefaciens. Biocat Biotrans 24:419-425.

Fischer-Colbrie G, Matama T, Heumann S, Martinkova L, Cavaco Paulo A, Guebitz G. 2007. Surface hydrolysis of polyacrylonitrile with nitrile hydrolysing enzymes from Micrococcus luteus BST20. J Biotechnol 129:62-68.

Glieder A, Farinas ET, Arnold FH. 2002. Laboratory evolution of a soluble, self-sufficient, highly active alkane hydroxylase. Nat Biotechnol 20:1135-1139.

Guebitz GM, Cavaco-Paulo A. 2008. Enzymes go big: surface hydrolysis and functionalisation of synthetic polymers. Trends Biotechnol 26:32-38.

Han S, Koh SK, Yoon KH. 1999. Induced surface reactions and chemical states - A kiloelectronvolt ion irradiation on simple linear chain structure polymers in an O-2 environment. J Electrochem Soc 146:4327-4333.

Herrero-Acero E, Ribitsch D, Steinkellner G, Gruber K. Greimel K, Eiteljoerg I, Trotscha E, Ren W, Zimmerman W, Zinn M, Cavaco-Paul A, Freddi G, Schwab H, Guebitz GM. 2011. Enzymatic surface hdrolysis of PET: effect of structural diversity on kinetic properties of cutinases from Thermobifida. Macro$\mathrm{mol}$ in press.

Heumann S, Eberl A, Fischer-Colbrie G, Pobeheim H, Kaufmann F, Ribitsch D, Cavaco-Paulo A, Guebitz GM. 2009. A novel aryl acylamidase from nocardia farcinica hydrolyses polyamide. Biotechnol Bioeng 102:1003-1011.

Naga N, Tsuchiya G, Toyota A. 2006. Synthesis and properties of polyethylene and polypropylene containing hydroxylated cyclic units in the main chain. Polymer 47:520-526.
Negoro S, Ohki T, Shibata N, Mizuno N, Wakitani Y, Tsurukame J, Matsumoto K, Kawamoto I, Takeo M, HiguchiY. 2005. X-ray crystallographic analysis of 6-aminohexanoate-dimer hydrolase - Molecular basis for the birth of a nylon oligomer-degrading enzyme. J Bus Comm 280:39644-39652.

Peters MW, Meinhold P, Glieder A, Arnold FH. 2003. Regio- and enantioselective alkane hydroxylation with engineered cytochromes P450 BM-3. JACS 125:13442-13450.

Ribitsch D, Heumann S, Trotscha E, Acero EH, Greimel K, Leber R, Birner-Gruenberger R, Deller S, Eiteljoerg I, Remler P, Weber T, Siegert P, Maurer KH, Donelli I, Freddi G, Schwab H, Guebitz GM. 2011. Hydrolysis of polyethyleneterephthalate by para-nitrobenzylesterase from Bacillus subtilis. Biotechnol Progr. 27:951-960.

Schroeder M, Fatarella E, Kovac J, Guebitz GM, Kokol V. 2008. Laccase-induced grafting on plasma-pretreated polypropylene. Biomacromolecules 9:2735-2741.

Schwaneberg U, Schmidt-Dannert C, Schmitt J, Schmid RD. 1999a. A continuous spectrophotometric assay for P450 BM-3, a fatty acid hydroxylating enzyme, and its mutant F87A. Anal Biochem 269:359-366.

Schwaneberg U, Sprauer A, Schmidt-Dannert C, Schmid RD. 1999b. P450 monooxygenase in biotechnology: I. Single-step, large-scale purification method for cytochrome P450 BM-3 by anion-exchange chromatography. J Chromatogr A 848: 149-159.

Vertommen MAME, Nierstrasz VA, Veer Mvd, Warmoeskerken MMCG. 2005. Enzymatic surface modification of poly(ethylene terephthalate). J Biotechnol 120:376-386. 